\title{
Construction of First-class Undergraduate Major Under the Guidance of Emerging Engineering Education
} A Case Study of Network Engineering

\author{
Huanhai Yang ${ }^{1, *}$ \\ ${ }^{1}$ School of Computer Science and Technology, Shandong Technology and Business University, Yantai, \\ Shandong 264005, China \\ *Corresponding author. Email: 201511809@sdtbu.edu.cn
}

\begin{abstract}
The network engineering major is a typical major that meets the requirements of "Emerging Engineering Education" talent training. This major needs to cultivate students' engineering awareness and practical skills, and foster applied engineering talents with the ability of network system planning, implementation, evaluation, operation and maintenance. According to the requirements of "Emerging Engineering Education" and "Firstclass Majors" for the training of network engineering talents, the network engineering specialty in Shandong Technology and Business University has revised the talent training scheme, has optimized the curriculum system, has strengthened the integration of industry and education, and has improved innovative minds. Some experience and achievements have been obtained, which can provide reference for training of network engineering talents in relevant colleges and universities.
\end{abstract}

Keywords: Emerging Engineering Education, First-class majors, Network engineering, Talent training, Curriculum system.

\section{INTRODUCTION}

In recent years, many universities actively responded to the requirements of the construction of "Emerging Engineering Education", strengthened the construction of first-class majors, comprehensively improved the quality of engineering education, and provided engineering and technical talents for a new round of scientific and technological revolution and industrial reform in China. Network engineering is a relatively new computer specialty. It cultivates technical talents who have solid professional knowledge in the field of computer science and network technology and can engage in application research based on network protocol, planning and deployment of network engineering and network security maintenance.
The network engineering major of Shandong Technology and Business University actively explores the reform of the training mode of excellent engineering talents, and was approved as a provincial first-class major in 2020 . In the reform of specialty construction, an action plan is put forward to dynamically update the talent cultivation scheme according to the industrial development, and the curriculum system is built up according to the latest technological development, which actively introduce relevant industry standards, strengthen the integration of industry and education and innovative education, and cultivate network engineering talents who can adapt to the industrial development.

*Fund: This study was supported by Higher Education Teaching Reform Project of Shandong Province in China (NO. M2018X178). 


\section{REFORMING AND EXPLORING TALENT TRAINING SCHEME}

\subsection{Mutual Integration of Ideological and Political Education, and Professional Teaching}

It is essential to integrate the objectives and requirements of ideological and political education into the talent training program. Graduates of network engineering should have the spirit of research, craftsmanship and social responsibility. According to the requirements of talent training objectives of first-class majors, the cultivation of ideological and political literacy is integrated into professional teaching. According to the training objectives and teaching objects of the course, relevant materials are collected, and eventually a database of ideological and political teaching resources has been built up. It is necessary to train students' engineering practice ability, and it's more significant to require them to foster a strong sense of mission and responsibility, engineering professional ethics and professionalism.

\subsection{Updating Talent Cultivation Scheme According to Industrial Development Trends}

With the rapid development of computer technology, communication technology and nextgeneration network technology, new computer network technologies and new equipment are constantly emerging. Students should timely grasp the latest technical trends in the industry and learn new technologies. The network engineering major at the university actively communicates with many enterprises, and the revision of the talent cultivation plan is carried out by the cooperation between the school and the enterprises, giving full play to the advanced technological advantages of the enterprises in order to cultivate applied and innovative talents that meet the needs of the society [1].

In the process of revising the talent training program, both schools and enterprises jointly discussed the talent cultivation requirements of "first-class majors", and jointly discussed the setting-up of the courses, the review of syllabus, and the reform plan of training mode based on the latest network technology. In order to realize the long-term development of collaborative education between schools and enterprises, the talent cultivation plan will be updated regularly according to the development of the industry. The network engineering major at the university has conducted in-depth discussions with Huawei, Huasan communication technology Co, Ltd., Inspur group, Jiangsu future networks innovation institute and other enterprises and scientific research institutions to jointly cultivate practical talents urgently needed by enterprises.

\section{3 "People-oriented" Personalized Talent Training Model}

Based on the individualized development of students, the school is inclined to teach students in accordance with their aptitude, construct a diversified training program, and set up two subject directions of intelligent network computing expansion module and network application development expansion module for students to choose. After students have completed the basic courses of the subject and the core compulsory courses of the major, they can choose elective courses of different expansion modules, which can not only meet the needs of students' differentiated development to the greatest extent, but also meet the integrity of the curriculum system.

In order to encourage the individual development of students, the school has established a multi-dimensional evaluation mechanism based on procedural assessment. It is the percentage of traditionally-single-examination mode that should be reduced. On the other hand, students' practical ability, teamwork ability and innovation ability should be examined through various methods, such as course design papers, innovative experiments, and enterprise project training. For example, in the assessment of "network planning and design", the teacher issued topics such as "application of optical fiber communication technology in campus network", "application of dynamic routing technology in campus network" and "analysis of campus network generic cabling system". Students submit course papers of no less than 3000 words in groups as performance assessment. The assessment method in which students choose topics of interest to explore stimulates students' learning enthusiasm, cultivates students' ability to solve problems by using their learned knowledge, and meets the personalized development needs. 


\section{UPDATING THE CURRICULUM SYSTEM ACCORDING TO THE LATEST TECHNOLOGY}

In the course system construction, the new technology of network engineering should be completely considered, the new trend of network technology development be regularly studied, and a reasonable and scientific curriculum system be gradually developed and periodically updated according to the latest needs of enterprises for network engineering talents. Adhering to the teaching idea of "taking the development of students as the foundation and guided by the needs of the industry", three course groups are formed: network engineering planning and design, network operation and maintenance and network security, and future network design.

Before the reform of the curriculum system of this major, there were problems such as repeated contents and a few outdated knowledge points. For example, some teaching contents of "network planning and design" were also involved in "routing and switching" and "network security". Therefore, the course of "network planning and design" was adjusted as a practical course to cultivate students' network design and deployment ability. According to the needs of enterprises, new network technology courses such as "intelligent network, scheduling and optimization" and "software defined network" are added.

The practical curriculum system should be developed jointly with enterprises to maintain the foresight and comprehensiveness of the experimental content. The content of practical teaching should keep close contact with social needs and keep pace with professional technology. The real projects from the enterprises are integrated into the teaching, in order to cultivate the students' ability to flexibly apply the learned knowledge in the engineering scene [2].

It is indispensable to establish a variety of practical teaching methods such as curriculum experiment, curriculum comprehensive design experiment, independent practice course, project training, and technological innovation course, which increases the practice teaching hours. The practice hours of this major account for more than $40 \%$. With the installment of the latest network equipment, seventeen professional laboratories and one training center have been constructed in the university. The labs include network engineering two-way teaching laboratory, network engineering training center, innovation laboratory of Internet of things, network information innovation laboratory, and generic cabling laboratory, fully meeting the needs of practical teaching in the university.

The practical content should reflect the application of new technology, and the practice training syllabus should be revised regularly. It should be clearly stipulated in the syllabus that new technology should be applied to the planning, implementation and assessment of experiments [3]. Teachers are encouraged to actively carry out the reform in experimental teaching, regularly update the experimental teaching content, develop comprehensive and innovative experimental projects based on new technology and enterprise application, and train students' comprehensive application ability, innovation ability and engineering consciousness.

\section{STRENGTHENING THE INTEGRATION OF INDUSTRY AND EDUCATION}

As a community of talent training, universities and enterprises should fully cooperate and combine their respective advantages to cultivate talents in line with societal needs. Teachers should actively communicate with enterprises, master the latest network technology, find topics and carry out research, and try to help enterprises solve technical problems [4]. Colleges and universities should often invite enterprises' technicians to give lectures and practical teaching. In recent years, the specialty has established twelve practice bases with some enterprises, has approved three industry-university cooperation collaborative education project, and has established a practical teaching mode, combining in-school experiment and enterprises' practice.

Numerous teachers have been regularly sent to cooperative enterprises to participate in "dualqualification" teacher training to fill in teachers' engineering background knowledge. Teachers learn the most cutting-edge technology in the enterprises, improve teachers' engineering practice ability and teaching level, and avoid the phenomenon of reading according to the textbooks in the teaching process [5].

In cooperation with enterprises, universities can also make full use of enterprises' equipment resources. Some network equipment is expensive and the school funds are limited, so it is difficult to achieve complete self-sufficiency of experimental 
resources. The network engineering specialty and cooperative enterprises jointly build up multiple laboratories that can be shared by either party. The laboratories jointly built by both parties can provide experimental teaching support for the school, operation training support for enterprises, and project cooperation between schools and enterprises. Schools and enterprises can cooperate to build a practical teaching case base. The sources of cases can be experiments, comprehensive design, curriculum design, graduation design and actual projects of enterprises. Teachers can discuss with enterprise technicians, prepare detailed practical guidance for students, and guide students to participate in discipline competitions, innovation and entrepreneurship [6].

\section{INNOVATING TALENT TRAINING MECHANISM}

It is necessary to encourage students to take part in professional competitions such as "network attack and defense competition", "C4-network technology challenge" and "future network innovation competition", and create innovative talents training mechanism with "promoting learning through competition". This major has established a practice team of innovation and entrepreneurship. Under the guidance of experienced teachers, it organizes students to actively sign up for various competitions to promote learning and improve their practical innovation ability [7].

The competition topics related to network engineering correlate with the latest network technology. By guiding the competition, teachers can carry out targeted research on the teaching content. In order to better solve the problems encountered by students in the competition process, teachers must learn the frontier knowledge of disciplines, strengthen their professional quality, and constantly follow up the new requirements of industrial development for professional curriculum theoretical knowledge, so as to meet the diversified training needs of students. By participating in the competition, students can find weaknesses in theoretical learning and practical application, mobilize learning enthusiasm, clarify learning direction, and improve personal comprehensive ability [8].

\section{ESTABLISHING TEACHING QUALITY GUARANTEE SYSTEM}

According to the goal orientation of talent training and the operation law of teaching work, the network engineering specialty of our university has formulated clear, scientific and reasonable quality standard for each teaching link [9]. It is essential to establish evaluation standards for various teaching links such as training program construction, curriculum system construction, theoretical teaching, practical teaching, and graduation design, and accordingly a scientific and standardized quality guarantee system will been formed.

The evaluation of teaching quality should be student-centered and pay attention to students' learning experience and gains. The student-centered quality assurance system has become a new perspective of higher education quality evaluation. It is important to enrich the channels for students to participate in teaching evaluation, and carefully listen to and collect students' opinions and suggestions on teaching and the construction of the major [10]. To promote the overall development of students as the goal, the teaching quality assurance system needs to be reconstructed. Students are the direct stakeholders in the guarantee of teaching quality, and the quality of teaching directly affects the ability of students to acquire knowledge [11].

Undergraduate teaching reform should be conducive to student development. This major implements a class teacher system and regularly listens to students' responses to teaching methods, teaching materials, examinations and other links. It is crucial to change the mode that students can only evaluate teaching online at the end of the semester, into the new one to enable them to participate in the periodic teaching quality evaluation by means of irregular symposium, questionnaire survey, interview of graduating students and so on [12]. This major ensures that students fully participate in the evaluation of teaching quality, and timely carry out teaching reform according to the evaluation results, so as to greatly improve the teaching quality.

\section{CONCLUSION}

Under the guidance of the "Emerging Engineering Education", the network engineering specialty in the university adheres to ensuring the teaching investment, constantly improving the school running conditions and improving the teaching quality. Comprehensive ability training 
should be taken as the main line, by revising the training scheme in combination with industrial development and the latest technology, hence to cultivate excellent engineering talents in line with the international standards. The cooperation with cooperative enterprises will strengthen theoretical teaching, experimental training and other links, and eventually students' comprehensive application ability will be improved. The innovation practice and competition activities will foster students' innovation consciousness. The student-centered teaching quality evaluation will be carried out, and teaching quality will be continuously improved, therefore the first-class major will be established with the aim of students' all-round development.

\section{AUTHORS' CONTRIBUTIONS}

This paper is independently completed by Huanhai Yang.

\section{ACKNOWLEDGMENTS}

Thank Terry, a British English teacher, and Mingyu Sun, a Chinese English teacher, for providing English polish for the paper.

\section{REFERENCES}

[1] H. M. Yang, N. W. Cai, L. L. Feng., and Ch. Z. Chen, "Research and Practice on Talent Cultivation and Resource Construction under the Mechanism of Industry University Cooperation," Education Teaching Forum, vol. 44, pp. 30-31, June 2017.

[2] Jing'ai L and Weiqing L., "Research on talent training model of new applied undergraduate colleges," International Journal of Information and Education Technology, vol. 9, pp. 652660, September 2019.

[3] B. Ni, Zh. Y. Liu, P. Ji, F. Zhang, and F. Li, "Reform and practice of practical teaching system network engineering based on 'Course certificate symbiosis and module serial' ". Experimental Technology and Management, vol. 7, pp. 200-203. July 2020.

[4] G. Jun, D. Chen, S. Yang, J. Dai, and B. Xie, "Exploration and Practice of Practical Teaching Architecture of Network Engineering to Engineering Capabilityoriented Cultivating," Computer Education, vol. 7, pp. 108-112, April 2010.
[5] Y. Ao, Zh. Wang, G. Yang, Y. Wang, and G. Sun, "Exploration and Practice on the Construction of First-class Undergraduate Majors in Local Universities: Taking Changchun University of Technology Chemical Major as an Example," Education and Teaching Forum, vol. 38, pp. 95-98, September 2021.

[6] Y. Bai, "Exploration and Practice of Network Engineering Reform," Education Modernization, vol 39, pp. 55-58, May 2020.

[7] Y. Qi and Y. Jiang, "Exploration of the Practical Teaching Mode of 'Competition to Promote Teaching and Learning' in Universities", Journal of Shanxi University of Finance and Economics, vol. 42, pp. 8386+89, April 2020.

[8] L. Wang and N. Gao, "Construction of Undergraduate Course Teaching Quality Evaluation Index--Perspective Based on Student's Perspective", Research in Higher Education of Engineering. vol. 2, pp. 195-200, February 2021.

[9] Q. Li, "On the "Student-Centered" University Teaching Quality Guaranteeing System", Journal of Yangzhou University (Higher Education Study Edition). vol. 4, pp. 1-7, 2021.

[10] X. Shi and Y. Xu, "The Construction of Talent Cultivation System Driven by Engineering Education Accreditation and ProductionEducation Integration", Research in Higher Education of Engineering, vol. 2, pp. 3339+56, February 2019.

[11] Y. Gao, T. Fu and Y. Sun, "On CDIO Mode Promotes Networking Engineering Teaching Reform and Practice with Project Driven", Journal of Southwest China Normal University (Natural Science Edition). vol. 44, pp. 33-39+56, April 2019.

[12] G. Cui and J. Gao. "Research on practice system for Network Engineering Major based on OBE", Experimental Technology and Management. Vol. 35, pp. 167-170+173, August 2018. 